University of Texas Rio Grande Valley

ScholarWorks @ UTRGV

$12-1-2016$

\title{
Subspecific and breeding status of the Common Yellowthroat (Geothlypis trichas) at Santa Ana National Wildlife Refuge, Hidalgo County, Texas
}

Timothy Brush

The University of Texas Rio Grande Valley

Mark H. Conway

Follow this and additional works at: https://scholarworks.utrgv.edu/bio_fac

Part of the Biology Commons

\section{Recommended Citation}

Brush, T., \& Conway, M. H. (2016). Subspecific and breeding status of the Common Yellowthroat (Geothlypis trichas) at Santa Ana National Wildlife Refuge, Hidalgo County, Texas. The Southwestern Naturalist, 61(4), 321-324. https://doi.org/10.1894/0038-4909-61.4.321

This Article is brought to you for free and open access by the College of Sciences at ScholarWorks @ UTRGV. It has been accepted for inclusion in Biology Faculty Publications and Presentations by an authorized administrator of ScholarWorks@ UTRGV. For more information, please contact justin.white@utrgv.edu, william.flores01@utrgv.edu. 


\section{Subspecific and breeding status of the Common Yellowthroat (Geothlypis trichas) at Santa Ana National Wildlife Refuge, Hidalgo County, Texas}

Authors: Brush, Timothy, and Conway, Mark H.

Source: The Southwestern Naturalist, 61(4) : 321-324

Published By: Southwestern Association of Naturalists

URL: https://doi.org/10.1894/0038-4909-61.4.321

BioOne Complete (complete.BioOne.org) is a full-text database of 200 subscribed and open-access titles in the biological, ecological, and environmental sciences published by nonprofit societies, associations, museums, institutions, and presses.

Your use of this PDF, the BioOne Complete website, and all posted and associated content indicates your acceptance of BioOne's Terms of Use, available at www.bioone.org/terms-of-use.

Usage of BioOne Complete content is strictly limited to personal, educational, and non - commercial use. Commercial inquiries or rights and permissions requests should be directed to the individual publisher as copyright holder.

BioOne sees sustainable scholarly publishing as an inherently collaborative enterprise connecting authors, nonprofit publishers, academic institutions, research libraries, and research funders in the common goal of maximizing access to critical research. 


\title{
NOTES
}

The Southwestern Naturalist 61(4): 321-324

\section{SUBSPECIFIC AND BREEDING STATUS OF THE COMMON YELLOWTHROAT (GEOTHLYPIS TRICHAS) AT SANTA ANA NATIONAL WILDLIFE REFUGE, HIDALGO COUNTY, TEXAS}

\author{
Timothy Brush* and Mark H. Conway
}

\begin{abstract}
Department of Biology, University of Texas Rio Grande Valley, 1201 West University Drive, Edinburg, TX 78539 (TB)
Lower Rio Grande Valley Avian Research, 2106 Emerald Lake Drive, Harlingen, TX 78550 (MHC)

*Correspondent: timothy.brush@utrgy.edu
\end{abstract}

\begin{abstract}
We confirmed the breeding of the Common Yellowthroat (Geothlypis trichas) during 2008-2015 at Santa Ana National Wildlife Refuge and presented measurement evidence that individuals belong to the Brownsville Common Yellowthroat, Geothlypis trichas insperata. This expands the known breeding distribution for this rare and local subspecies.

RESUMEN-Se confirmó la reproducción de la mascarita común (Geothlypis trichas) durante 2008-2015 en Santa Ana National Wildlife Refuge y se presentaron pruebas de medición que indican que los individuos pertenecen a la subespecie de mascarita común, Geothlypis trichas insperata. Esta información expande la distribución de reproducción conocida de esta subespecie rara y local.
\end{abstract}

The Common Yellowthroat (Geothlypis trichas) is a bird species breeding in wetlands across much of North America (Zink and Klicka, 1990; Guzy and Ritchison, 1999). Lockwood and Freeman (2014) list four subspecies breeding in Texas. One of these is the Brownsville Common Yellowthroat (Geothlypis trichas insperata), a sedentary subspecies endemic to the Lower Rio Grande Valley of Texas and adjacent Mexico (Oberholser, 1974). In 1908, before the subspecies was described, Frank B. Armstrong collected a female still in juvenile plumage across the Rio Grande in Matamoros, Tamaulipas, Mexico (Phillips, 1911). The subspecies was described from seven specimens, including two in juvenile plumage, taken in 1930 by H. H. Kimball downstream from Brownsville (Van Tyne, 1933). Klicka (1994) confirmed breeding of this subspecies in moist resaca (old river channel) habitats dominated by grasses (Paspalum sp.) with scattered shrubs (Mimosa pigra, Salix exigua, Baccharis neglecta) or reeds (Arundo donax or Phragmites communis; scientific names of plants from Richardson and King, 2011). He estimated a population of 100-150 breeding pairs in southern Cameron County but did not find any breeding birds in Hidalgo or Starr counties. Klicka (1994) expressed concern about the conservation status of the subspecies, given its small range and limited habitat under threat of development.

Between 1991 and 2002, Brush (2005) found a population of five or more territories of Common Yellowthroats during the breeding season at Santa Ana National Wildlife Refuge $\left(26^{\circ} 04^{\prime} 24^{\prime \prime} \mathrm{N}, 98^{\circ} 08^{\prime} 58^{\prime \prime} \mathrm{W}, 23-\right.$ 40 m elevation; hereafter, Santa Ana NWR) and smaller numbers at other locations in Hidalgo County, Texas. Brush (2005) suspected that the Santa Ana NWR birds might belong to Geothlypis trichas chryseola, which occurs upriver along the Rio Grande in Texas and the remaining U.S.-Mexico border region (Oberholser, 1974; Lockwood and Freeman, 2014), given different song types and their use of cattail (Typha domingensis)-dominated marsh habitat. Roy et al. (2013) performed a genetic study in May-August 2008 and 2009 and concluded that a freely dispersing population of Brownsville Common Yellowthroats occurred at their 10 sites in Cameron County and also Santa Ana NWR (Hidalgo County). We used bird banding to determine the subspecific identity and current breeding status of Common Yellowthroats at Santa Ana NWR.

We captured and banded Common Yellowthroats during the breeding seasons of 2008-2015 and report here on banding conducted from June through early 


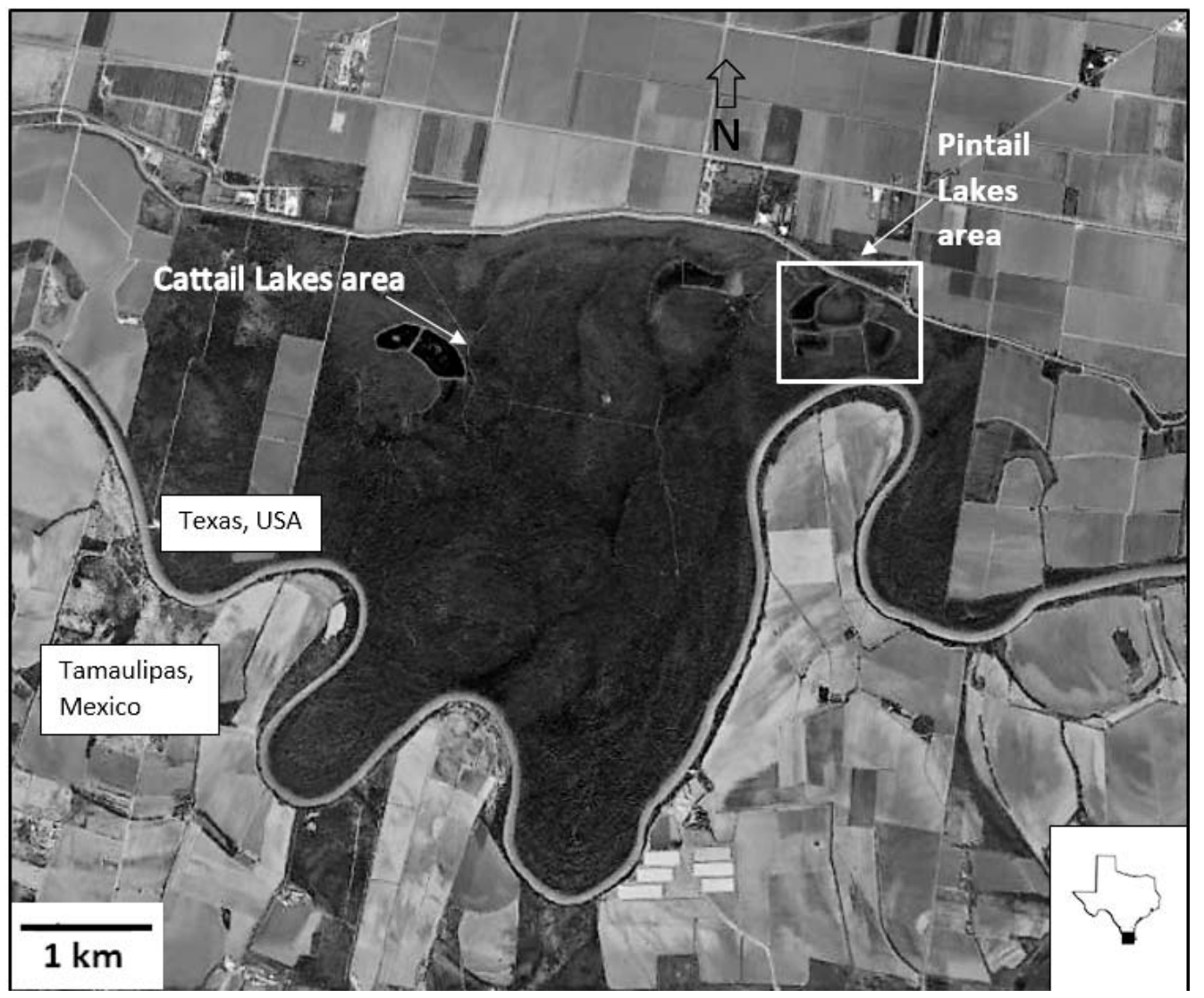

Fig. 1-Santa Ana National Wildlife Refuge, Hidalgo County, Texas, showing our main location in the Pintail Lakes area where Common Yellowthroats were banded during breeding seasons of 2008-2015 and the secondary banding location in the Cattail Lakes area.

August when only breeding birds should be present. Nearly all banding was done in the Pintail Lakes section of Santa Ana NWR because this area supported the largest numbers of Common Yellowthroat territories (TB, pers. obser.; Fig. 1). Approximately 50\% of the 26.1 ha making up the Pintail Lakes section contained emergent marsh habitat dominated by cattail and bulrush (Scirpus species) due to varying amounts of rainfall in the region and differing management practices. In particular, prolonged high water in 2010 limited our access to Pintail Lakes and removed most vegetation from those wetland units. As a result, in 2011 we banded at Cattail Lakes, where a limited amount of wetland vegetation dominated by smartweed (Persicaria pensylvanica) and golden-fruited dock (Rumex chrysocarpus) was used by yellowthroats. By 2012, wetland vegetation and yellowthroats returned to Pintail Lakes, so we resumed banding there through 2015.

MHC did the banding, assisted by $2-4$ people using nylon mist nets with 30-mm mesh. Most nets were placed parallel to the shoreline but some were placed within the wetland vegetation if conditions allowed. All birds (with a few exceptions due to escapes) were banded with standard U. S. Fish and Wildlife Service aluminum bands and released after morphological data were recorded. We banded from sunrise to approximately $1030 \mathrm{~h}$ to assure safe conditions for the captured birds. We measured wing length, tail length, bill dimensions, lengths of selected toes, presence of brood patches or cloacal protuberances, and estimated feather wear. We also recorded other measurements such as primary 9 minus primary 4 (p9 p4; thought to be crucial for determining subspecific identity), bill color (indicative of breeding status in males), and coloration of plumage areas suggested by Van Tyne (1933), Klicka (1994), and Pyle (1997) as means of distinguishing subspecies.

We captured 61 yellowthroats at Santa Ana during June-early August 2008-2015 (Table 1). Numbers of birds captured annually varied from 2-15 depending on habitat conditions and banding intensity. Habitats where birds were captured varied from cattail-dominated to mixed herbaceous wetlands. We banded 24 adult males, $45.8 \%$ of which had cloacal protuberances (one escaped before all observations were made). We banded 12 adult females, 11 of which had brood patches (one of these contained an unlaid egg in her lower abdominal region when banded). We caught 25 juveniles, with a peak of 10 in 2012 (40\% of the total; Table 1). We estimated that more than five territorial males were present at Pintail Lakes in all years except 2010 and 2011 (TB, pers. obser.).

$T$-tests of measurement variables revealed significant 
TABLE 1-Banding effort and numbers of adult (male, female) and juvenile (unsexed) Common Yellowthroats banded at Santa Ana National Wildlife Refuge during breeding seasons of 2008-2015.

\begin{tabular}{lccrr}
\hline \hline Year & Banding days & Net hours & Adults, $n(\mathrm{M}, \mathrm{F})$ & Juveniles \\
\hline 2008 & 4 & 105.0 & $7(4,3)$ & Total \\
2009 & 5 & 127.0 & $10(8,2)$ & 9 \\
2010 & 3 & 77.8 & $2(0,2)$ & 3 \\
2011 & 4 & 92.5 & $1(1,0)$ & 0 \\
2012 & 6 & 111.0 & $5(4,1)$ & 2 \\
2013 & 3 & 43.5 & $6(3,3)$ & 13 \\
2014 & 3 & 56.2 & $2(2,1)$ & 4 \\
2015 & 2 & 30.0 & $36(24,12)$ & 0 \\
Total & 30 & 653.0 & 4 & 3 \\
\end{tabular}

variation between adults and juveniles only for $\mathrm{p} 9-\mathrm{p} 4$ and bill length (Table 2). In juveniles, p9 averaged 2.16 $\mathrm{mm}$ shorter than $\mathrm{p} 4$. This was a greater difference than among adults, in which p9 averaged only $0.82 \mathrm{~mm}$ shorter than $\mathrm{p} 4$. Twenty-two adults had obvious wear to $\mathrm{p} 4$ whereas four adults had obvious wear to $\mathrm{p} 9$ and $\mathrm{p} 4$. One juvenile had incomplete development of p4. Bill length (culmen) was $0.39 \mathrm{~mm}$ longer in adults than in juveniles.

Plumage coloration varies among subspecies, but we found it difficult to rigorously assign shades of color that might be useful in determining subspecies. However, we did find that the frontal band was whitish in all but two individuals. An adult male banded on 9 June 2012 was noted as having extensively yellow underparts and had a yellowish tinge in his postfrontal bar, both suggestive of $G$. t. chryseola. Unfortunately, $\mathrm{p} 4$ was broken on both sides, so we could not get a measurement of p9 - p4.

We found evidence that Common Yellowthroats were breeding at Santa Ana NWR during our study, given the presence of brood patches in nearly all females, cloacal protuberances in almost half the males, and the capture of 25 juveniles. We did not look for nests but suspect that they were low in wetland vegetation, as Klicka (1994) and other studies (summarized in Guzy and Ritchison, 1999) have found. Despite the 2010 floods, which temporarily cleared most of the wetland vegetation from our Pintail Lakes study area, yellowthroats responded favorably when the vegetation returned, consistent with the genetic evidence for frequent dispersal between wetlands in the Lower Rio Grande Valley (Roy et al., 2013).

Several measurements and other observations suggest that the Brownsville Common Yellowthroat is the subspecies breeding at Santa Ana NWR. The fact that p9 was significantly shorter than p4 strongly suggests that this population is not G. t. chryseola, in which $\mathrm{p} 9$ is $0-4 \mathrm{~mm}$ longer than p4 (Pyle, 1997). A smaller sample of birds banded by MHC in 2013-2016 at The Nature Conservancy's Lennox Southmost Preserve in Cameron County, where G. t. insperata is known to nest (Klicka, 1994), showed similar $\mathrm{p} 9-\mathrm{p} 4$ values: adults averaged $-0.70 \mathrm{~mm}$ $(n=10)$ and juveniles $-2.0 \mathrm{~mm}(n=4)$. Similarly, the wing lengths of the birds from Santa Ana NWR, averaging $\sim 53 \mathrm{~mm}$, are closer to the G. $t$. insperata average of $\sim 55$ than to the G. $t$. chryseola average of $\sim 58 \mathrm{~mm}$. Finally, the average outer tail-feather length of $\sim 45 \mathrm{~mm}$ for the birds from Santa Ana NWR is closer to the G. t. insperata average of $\sim 44 \mathrm{~mm}$ than to the G. $t$. chryseola average of $\sim 48 \mathrm{~mm}$ (Oberholser, 1974; Klicka, 1994).

It is encouraging that Brownsville Common Yellow-

TABLE 2-Morphological measurements ( $\mathrm{mm}$ ) of Common Yellowthroats banded at Santa Ana NWR, Hidalgo County, Texas, during breeding season in June-August 2008-2015. Data are presented as mean $\pm S D(n)$. Birds were classified as juveniles (in their first year) or adults (in their second year or later). Overall means are presented if there was no significant difference between age classes; otherwise, the $P$-value of the adult-juvenile $t$-test comparison is shown.

\begin{tabular}{|c|c|c|c|}
\hline Measurement & Adults & Juveniles & Overall \\
\hline Wing length (chord) & $53.70 \pm 2.12$ & $52.68 \pm 2.04(25)$ & $53.20 \pm 2.20(59)$ \\
\hline Tail & $49.12 \pm 3.09(24)$ & $50.65 \pm 2.25(23)$ & $49.87+2.76(47)$ \\
\hline Outermost tail feather & $44.04 \pm 3.39$ & $45.78 \pm 2.50$ & $44.91 \pm 3.08(46)$ \\
\hline Bill length (culmen) & $11.99 \pm 0.55$ & $11.60 \pm 0.52(24)$ & $P<0.0086$ \\
\hline Nares to tip & $8.43 \pm 0.47(35)$ & $8.18 \pm 0.54(24)$ & $8.33 \pm 0.51(59)$ \\
\hline Tarsus length & $21.89 \pm 1.13$ & $21.31 \pm 1.12(24)$ & $21.65 \pm 1.15(59)$ \\
\hline Hind toe with claw & $12.31 \pm 1.05$ & $12.48 \pm 1.24(24)$ & $12.38 \pm 1.12(59)$ \\
\hline Hind toe without claw & $7.73 \pm 0.53(30)$ & $7.56 \pm 0.62(22)$ & $7.66 \pm 0.57(52)$ \\
\hline
\end{tabular}


throats breed in Hidalgo County as well as Cameron County, but small populations and threats to wetland habitat such as urbanization and limited water availability in the Lower Rio Grande Valley warrant continued concern. Current wetland tracts in Hidalgo County are small, ranging from $1-5$ ha up to a few of $\sim 40$ ha, and many are maintained only by active management (U. S. Fish and Wildlife Service, 2016). Surveys of remnant wetlands in Hidalgo County suggest that the only other population of more than five pairs is in the cattaildominated wetland at Delta Lake County Park, $41 \mathrm{~km}$ NNE of Santa Ana NWR (TB, pers. obser.). In Cameron County, only the Sabal Palm Sanctuary and the Lennox Southmost Preserve are known to support similar numbers. Coastal wetlands such as those along the Laguna Madre in eastern Cameron County are often large, but there is no evidence yet that Common Yellowthroats breed in these brackish and saline wetlands (Brush, 2005). We suggest a long-term monitoring program throughout freshwater wetlands of the Lower Rio Grande Valley, to detect future population changes, as well as banding studies of Common Yellowthroats farther upstream along the Rio Grande to determine range limits for the subspecies.

We thank Santa Ana NWR (G. Chapa) and The Nature Conservancy (M. Pons) for allowing access and granting permission for this study. MHC banded birds under Federal Bird Banding Permit 22758 and Texas Scientific Permit SPR0703-314. S. Benn, C. C. Brush, and others aided with fieldwork.

\section{Literature Cited}

Brush, T. 2005. Nesting birds of a tropical frontier, the Lower Rio Grande Valley of Texas. Texas A\&M University Press, College Station, Texas.
Guzr, M. J., And G. Ritchison. 1999. Common Yellowthroat (Geothlypis trichas). The Birds of North America, Number 448 (A. Poole, editor). Cornell Laboratory of Ornithology, Ithaca, New York.

KLICKA, J. 1994. The biological and taxonomic status of the Brownsville Yellowthroat (Geothlypis trichas insperata). M.S. thesis, University of Minnesota, Minneapolis.

Lockwood, M. W., and B. Freeman. 2014. The TOS handbook of Texas birds. Second edition. Texas A\&M University Press, College Station.

Oberholser, H. C. 1974. The bird life of Texas. Volume 2. University of Texas Press, Austin.

Phillips, J. C. 1911. A years' collecting in the state of Tamaulipas, Mexico. Auk 28:67-89.

PyLe, P. 1997. Identification guide to North American birds, part 1. Slate Creek Press, Bolinas, California.

Richardson, A., AND K. King. 2011. Plants of Deep South Texas: a field guide to the woody and flowering species. Texas A\&M University Press, College Station.

Roy, C. L., C. J. Butler, and M. L. Haynie. 2013. Brownsville Common Yellowthroats maintain genetic diversity in a fragmented landscape. Wilson Journal of Ornithology 125:402-406.

U. S. Fish and Wildlife Service. 2016. National Wetlands Inventory website. U.S. Department of the Interior, Fish and Wildlife Service, Washington, D.C. http://www.fws.gov/ wetlands/

Van Tyne, J. 1933. Some birds of the Rio Grande Delta of Texas. Occasional Papers of the Museum of Zoology, University of Michigan, Number 255. Ann Arbor.

ZINK, R. M., AND J. T. KLICKA. 1990. Genetic variation in the Common Yellowthroat and some allies. Wilson Bulletin 102:514-520.

Submitted 11 July 2016.

Acceptance recommended by Associate Editor, Eddie Lyons, 9 September 2016.

\title{
SPATIAL VARIATION OF PARASITE INFRACOMMUNITIES IN THE AMERICAN ALLIGATOR (ALLIGATOR MISSISSIPPIENSIS)
}

\author{
Helen Sung and Marisa Tellez*
}

Department of Ecology and Evolutionary Biology, University of California, Los Angeles, Los Angeles, CA 90095 (HS)

Marine Science Institute, University of Santa Barbara, Santa Barbara, CA 93106 (MT)

*Correspondent: marisa.tellez@ucsb.edu

ABstract-Parasites were harvested from lungs and gastrointestinal tracts of Alligator mississippiensis from Texas. We compared our results with previous parasitism findings from alligators harvested in 2011 in Louisiana and Florida. Florida alligators exhibited the greatest pentastomid prevalence and mean intensity and illustrated higher stomach prevalence and intensity than other locations. Prevalence and mean intestinal parasitism of western Louisiana alligators differed significantly from other locations. Collectively, 14 species of trematodes and 7 species of nematodes were identified among Texas, Louisiana, and Florida. Differences in 